\title{
Diagnostic value of D2-40 immunostaining for malignant mesothelioma: a meta-analysis
}

\author{
Chao He ${ }^{1, *}$, Bo Wang ${ }^{2, *}$, Chun Wan ${ }^{3}$, Ting Yang ${ }^{3}$ and Yongchun Shen ${ }^{3}$ \\ ${ }^{1}$ Department of Laboratory Medicine, West China Hospital of Sichuan University, Chengdu 610041, China \\ ${ }^{2}$ Intensive Care Unit, West China Hospital of Sichuan University, Chengdu 610041, China \\ ${ }^{3}$ Department of Respiratory and Critical Care Medicine, West China Hospital of Sichuan University and Division of Pulmonary \\ Diseases, State Key Laboratory of Biotherapy of China, Chengdu 610041, China \\ *These authors have contributed equally to this work
}

Correspondence to: Yongchun Shen, email: shen_yongchun@126.com

Keywords: malignant mesothelioma, D2-40, diagnosis, meta-analysis

Received: March 10, $2017 \quad$ Accepted: June 18, $2017 \quad$ Published: July 06, 2017

Copyright: He et al. This is an open-access article distributed under the terms of the Creative Commons Attribution License 3.0 (CC BY 3.0), which permits unrestricted use, distribution, and reproduction in any medium, provided the original author and source are credited.

\begin{abstract}
Malignant mesothelioma (MM) has become a global disease burden for its rising incidence and invariable fatality. D2-40 has been widely used as an immunostaining marker of diagnosing MM, while its diagnostic value has not yet been evaluated. Our study aimed to assess the overall accuracy of D2-40 immunostaining for diagnosing MM through a meta-analysis. A total of 22 studies with 2,264 participants were identified from PubMed, EMBASE, Web of Science, Scopus and the Cochrane database. The pooled sensitivity and specificity of D2-40 for MM was 0.86 (95\% CI: $0.84-0.89$ ) and 0.77 (95\% CI: 0.74-0.79), respectively. The area under the summary receiver operating characteristic curve is 0.93 , with a diagnostic odds ratio 40.37 (95\% CI: 19.97-81.61). None of the study variates was found to be a source of heterogeneity after metaregression analysis. In conclusion, D2-40 immunostaining may not give sufficient evidence by itself to diagnose MM and should be in combination with other markers to improve the accuracy of diagnosis.
\end{abstract}

\section{INTRODUCTION}

Malignant mesothelioma (MM) is a highly aggressive carcinoma usually involving the pleura or peritoneum. Between 1994 and 2008, a total of 92,253 mesothelioma deaths has been reported to the World Health Organization from 83 countries, and the crude and ageadjusted mortality rates of mesothelioma were estimated as 6.2 and 4.9 per million population, respectively [1]. Moreover, an incidence peak was expected around 2020 according to the widespread exposure to asbestos [2]. Unfortunately, the patients suffering from MM showed poor response to the drug, and their median survival period was only 8 months (range 1 69 months) [3].

The diagnosis of carcinoma is usually based on histopathological examination on tissue or cytological specimens. Because morphological features of MM mimic those of a variety of other carcinomas, immunohistochemical markers have been used to improve the diagnostic performance, as recommended by International Mesothelioma Interest Group [4]. Whereas, several followup studies reported that the misdiagnosis rate of MM was high $(10 \% \sim 44 \%)$ [5-7], even much higher $(65 \%)$ in its pleural localization [8]. So, it is necessary to evaluate the diagnostic accuracy of the markers.

D2-40 is a commercial monoclonal antibody directed against the M2a antigen, which is associated with testicular and extratesticular seminomas and intratubular germ cell neoplasms [9]. Also, D2-40 is a marker for lymphatic endothelium and derived carcinomas [10]. In the past decade, D2-40 has been widely used as an immunostaining marker of diagnosing MM [4, 11-14]. However, the studies about its diagnostic accuracy obtained inconsistent results. Therefore, our study aimed to assess the overall accuracy of D2-40 immunostaining for diagnosing MM through a meta-analysis. 


\section{MATERIALS AND METHODS}

\section{Literature search and study selection}

We conducted an independent literature search to identify the relevant studies in PubMed, EMBASE, Web of Science, Scopus and the Cochrane database up to December 31, 2016. The search terms were "Mesothelioma", and "D2-40", and "sensitivity or specificity or accuracy". The reference lists of eligible studies were also manually searched to find the potential studies.

The included studies should meet all the following criteria: (1) it was an original study using D2-40 immunostaining to diagnose MM; (2) there was a diagnostic standard for MM; (3) there were sufficient data to generate a $2 \times 2$ table for calculating sensitivity and specificity; (4) it was published in English; (5) it involved at least 10 participants for case or control group.

Two independent researchers ( $\mathrm{CH}$ and $\mathrm{BW}$ ) screened and selected the eligible articles. Any disagreement between the two researchers was resolved by consultation with a third researcher (YCS).

\section{Data extraction and quality assessment}

Two researchers ( $\mathrm{CH}$ and $\mathrm{BW}$ ) manually extracted the following data from each study: author; publication year; research country; participant; specimen; specimen preparation method; D2-40 antibody (clone, dilution, source); cutoff of positive immunostaining; the number of true-positive, false-positive, true-negative, and false-negative results; study design; and blinding. At the same time, the methodological quality of these studies was evaluated using the Quality Assessment for Diagnostic Accuracy Studies (QUADAS) score [15]. The discrepancies were resolved through consultation with a third researcher (YCS).

\section{Statistical analyses}

The following parameters of diagnostic accuracy, together with their $95 \%$ confidence interval $(95 \% \mathrm{CI})$, were calculated: sensitivity, specificity, positive/negative likelihood ratio (PLR/NLR), and diagnostic odds ratio (DOR). Forest plots for sensitivity and specificity were constructed. Summary receiver operating characteristic (SROC) curve was generated, and area under the cure (AUC) was calculated to assess the overall diagnostic performance. Publication bias was tested using Deeks' funnel plots [16].

Potential heterogeneity among included studies was evaluated using the $\mathrm{I}^{2}$ inconsistency test. $\mathrm{I}^{2}>50 \%$ suggested substantial heterogeneity, which was subsequently analyzed through a meta-regression analysis to determine possible sources of heterogeneity among the studies.
All the statistical analysis was completed by MetaDiSc XI (Cochrane Colloquium, Barcelona, Spain) and STATA 12.0 (Stata Corporation, TX, USA) software. All statistical tests were two-sided, and statistical significance was set at $P<0.05$.

\section{RESULTS}

\section{Characteristics of included studies}

A total of 22 studies were identified according to the inclusion criteria in our meta-analysis $[5,8,17-36]$. The process of selecting studies was shown in Figure 1. The characteristics of these studies were listed in Table 1. Overall, these studies originated from 8 countries, and involved 2,264 participants comprising $862 \mathrm{MM}$ cases and 1,402 controls. The sample size of these studies varied from 20 to 282, with an average size of 103 participants. Lung carcinoma (778/1402, 55.5\%) was the predominating control group (Supplementary Table 1). Four studies performed D2-40 immunostaining of cell blocks from the effusions [17-20] and the remaining 18 studies assayed the tissues from surgical section, biopsy and/or autopsy [5, 8, 21-36]. As shown in Table 2, 20 studies had QUADAS scores $\geq 9$, suggesting the reliability of our meta-analysis results.

\section{Diagnostic accuracy of D2-40 immunostaining}

The pooled sensitivity and specificity of D2-40 for diagnosing MM was 0.86 (95\% CI: $0.84-0.89)$ and 0.77 (95\% CI: $0.74-0.79$ ), respectively (Figure 2). The AUC of SROC curve was 0.93 (Figure 3A). Other parameters of D2-40 for MM were listed in Table 3.

After subgroup analysis, diagnostic indices of D240 for each subtype of MM (epithelioid, or biphasic, and sarcomatoid) were shown in Figure 3B-3D and Table 3. Parameters of D2-40 for pleural MM were also listed in Table 3.

\section{Meta-regression}

$\mathrm{I}^{2}$ values for diagnostic performance indices were as follows: sensitivity, $82.8 \%(P=0.00)$; specificity, $93.1 \%$ $(P=0.00)$; PLR, $94.2 \%(P=0.00)$; NLR, $81.6 \%(P=$ $0.00)$; and DOR, $77.3 \%(P=0.00)$. These suggested high heterogeneity among included studies. Therefore, a metaregression analysis was performed based on eight variates: country of origin (USA vs others); sample size ( $<100$ or $\geq 100$ ); specimen type (effusion vs tissue); D2-40 antibody dilution ( $<1: 50$ vs others); cut-off value (Membranous staining vs others); study design (prospective vs others); and blinding (blind vs Not available); QUADAS score $(<9$ vs $\geq 9)$. None of these covariates was found to be a source of heterogeneity (all $P \geq 0.05$, Table 4). 
Table 1: Characteristics of included studies

\begin{tabular}{|c|c|c|c|c|c|c|c|c|c|}
\hline Author (Ref) & Year & Country & Participants & Specimen & $\begin{array}{c}\text { Specimen } \\
\text { preparation }\end{array}$ & Clone & Dilution & Source & Cut-off \\
\hline Bassarova AV [17] & 2006 & Norway & 282 & PE,PTE & Cell block & D2-40 & $1: 200$ & Dako & Membranous staining \\
\hline Saad RS [18] & 2006 & USA & 40 & $\mathrm{PE}$ & Cell block & D2-40 & $1: 50$ & Signet & Membranous staining \\
\hline Bhalla R [19] & 2007 & USA & 20 & PE,PTE & Cell block & D2-40 & $1: 100$ & Dako & Membranous staining \\
\hline Hyun TS [20] & 2012 & USA & 32 & $\mathrm{PE}$ & Cell block & D2-40 & $1: 50$ & Dako & Membranous staining \\
\hline Ordóñez NG [21] & 2005 & USA & 163 & Tissue & Tissue section & D2-40 & $1: 50$ & Signet & Membranous staining \\
\hline Chu AY [22] & 2005 & USA & 178 & Tissue & Tissue block & D2-40 & $1: 25$ & Signet & $\begin{array}{l}\text { Membranous and/or } \\
\text { Cytoplasmic staining }\end{array}$ \\
\hline Müller AM [23] & 2006 & Germany & 112 & Tissue & Tissue section & D2-40 & $1: 50$ & DCS & $\begin{array}{l}\text { Membranous and/or } \\
\text { Cytoplasmic staining }\end{array}$ \\
\hline Ordóñez NG [24] & 2006 & USA & 85 & Tissue & Tissue section & D2-40 & $1: 25$ & Signet & Membranous staining \\
\hline Comin CE [25] & 2007 & Italy & 55 & Tissue & Surgical resection & D2-40 & Pre-diluted & Signet & Membranous staining \\
\hline Mimura T [26] & 2007 & Japan & 132 & Tissue & Major resection & D2-40 & $1: 50$ & Dako & Membranous staining \\
\hline Padgett DM [27] & 2008 & USA & 145 & Tissue & $\begin{array}{l}\text { Surgical resection, } \\
\text { autopsy, slides }\end{array}$ & D2-40 & $1: 100$ & Signet & $\begin{array}{l}\text { Membranous or Cytoplasmic } \\
\text { staining }(>10 \% \text { cells stained, } \\
\text { moderate or strong intensity) }\end{array}$ \\
\hline Amatya VJ [28] & 2009 & Japan & 160 & Tissue & $\begin{array}{l}\text { Surgical resection, } \\
\text { autopsy }\end{array}$ & D2-40 & Pre-diluted & Nichirei & $\begin{array}{l}\text { Membranous and/or } \\
\text { Cytoplasmic staining }\end{array}$ \\
\hline Deniz H [29] & 2009 & Turkey & 73 & Tissue & Tissue section & D2-40 & NA & Dako & $\begin{array}{l}\text { Membranous staining } \\
(>5 \% \text { cells stained })\end{array}$ \\
\hline Takeshima Y [30] & 2009 & Japan & 72 & Tissue & Surgical section & D2-40 & Pre-diluted & Nichirei & $\begin{array}{l}\text { Membranous and/or } \\
\text { Cytoplasmic staining }\end{array}$ \\
\hline $\mathrm{Hu} \mathrm{YC}[31]$ & 2010 & USA & 67 & Tissue & $\begin{array}{l}\text { Surgical resection, } \\
\text { biopsy }\end{array}$ & D2-40 & $1: 100$ & Dako & $\begin{array}{l}\text { Membranous and/or } \\
\text { Cytoplasmic staining } \\
(>10 \% \text { cells stained })\end{array}$ \\
\hline Kao SC [32] & 2011 & Australia & 101 & Tissue & Surgical section & D2-40 & $1: 100$ & Signet & Membranous staining \\
\hline Comin CE [33] & 2014 & Italy & 247 & Tissue & $\begin{array}{l}\text { Surgical section, } \\
\text { biopsy }\end{array}$ & D2-40 & RTU & Ventana & Membranous staining \\
\hline Guo Z[8] & 2016 & China & 78 & Tissue & Biopsy & D2-40 & RTU & Dako & NA \\
\hline Kawai T [34] & 2016 & Japan & 33 & Tissue & $\begin{array}{l}\text { Biopsy, autopsy, } \\
\text { excision }\end{array}$ & D2-40 & RTU & Nichirei & $>10 \%$ cells stained \\
\hline Carbone M [5] & 2016 & USA & 55 & Tissue & Biopsy & D2-40 & NA & Dako & NA \\
\hline Amatya VJ [35] & 2017 & Japan & 60 & Tissue & Surgical section & D2-40 & Pre-diluted & Nichirei & Membranous staining \\
\hline Kushitani K [36] & 2017 & Japan & 74 & Tissue & $\begin{array}{l}\text { Biopsy, autopsy, } \\
\text { surgical section }\end{array}$ & D2-40 & Pre-diluted & Nichirei & Membranous staining \\
\hline
\end{tabular}

PE: Pleural effusion; PTE: Peritoneal effusion; NA: Not available; RTU: Ready to use.

\section{Publication bias}

The slope coefficient of Deeks' funnel plot was associated with a $P$ value of 0.48 , suggesting symmetry in the data and low likelihood of such kind of bias among the included studies (Figure 4).

\section{DISCUSSION}

The search for biomarkers, a cost-effective means of MM management, has been on-going for the past years [37]. D2-40 has emerged as a promising candidate, but the results of the studies remain controversial $[20,33,36]$. In our study, we determined the overall accuracy of D2-40 immunostaining in diagnosing MM through a metaanalysis.

Our meta-analysis found the pooled sensitivity and specificity was 0.86 and 0.77 respectively, suggesting a rate of missed diagnoses (14\%) and misdiagnosis (23\%) of D2-40 for diagnosing MM. The pooled DOR of D2-40 for MM was 40.37, which indicates a modest level of overall accuracy. The pooled PLR value of 5.15 suggests that the patients with MM have an approximately 5 -fold higher chance of giving a positive D2-40 result than do patients without MM. At the same time, the pooled NLR was 0.18 , indicating that a negative D2-40 result is $18 \%$ likely to be a false negative, which is not low enough to rule out MM. Thus, these findings suggested that D2-40 should be combined with other markers to improve the diagnostic accuracy. For example, several studies reported that D2-40 showed low specificity in distinguishing MM from ovarian carcinomas $[17,20,22]$. If the differential diagnosis of peritoneal MM from ovarian carcinomas is required, clinical history of the patient should be an important factor for evaluation. At the same time, the ovarian carcinoma markers, estrogen receptor etc., should be added into the 
immunohistochemical panel for avoiding a false-positive diagnosis of MM [38].

MM has distinctive histological subtypes: epithelioid $(60 \% \sim 80 \%)$, sarcomatoid $(<10 \%)$, and biphasic (10\% 15\%, composed of both epithelioid and sarcomatoid components) [39]. Our study further determined the diagnostic performance of D2-40 for these subtypes and found the performance of D2-40 for diagnosing epithelioid MM and biphasic MM is better than that for sarcomatoid MM. It indicated the reactivity to D2-40 antibody differed among these subtypes of MM. A relatively low pooled sensitivity $(0.65,95 \% \mathrm{CI}: 0.56-0.73)$ for sarcomatoid MM was obtained in our meta-analysis. However, Chirieac LR [40] have reported that all the $24(100 \%)$ cases of sarcomatoid MM were positive for D2-40 staining in their study, which was not included in our meta-analysis for lack of control group. Further work should be performed to elucidate this issue.
In diagnostic practice, pleural MM can easily be confused with metastatic carcinomas with the pleura involvement. Our meta-analysis has performed a subgroup analysis of pleural MM. We found that the sensitivity, specificity, and AUC of D2-40 for diagnosing pleural MM were $0.85,0.81$ and 0.93 , respectively. However, interpretation should be with caution when differentiating pleural MM from lung small cell carcinomas (SCC), because it was reported that D2-40 can stained $77 \%$ of lung SCC [5]. Recently, novel markers, such as BAP1 [5], MUC4 [35], fibulin-3 [41], have been used to improve the diagnostic accuracy of D2-40 for pleural MM.

Compared with histological diagnosis, cytological diagnosis of $\mathrm{MM}$ is minimally invasive and more easily performed. Because only 4 studies using cytology of effusions to diagnose MM can be included in our metaanalysis, the accuracy of diagnosing MM using cytology is hard to be evaluated accurately now. But the difference of

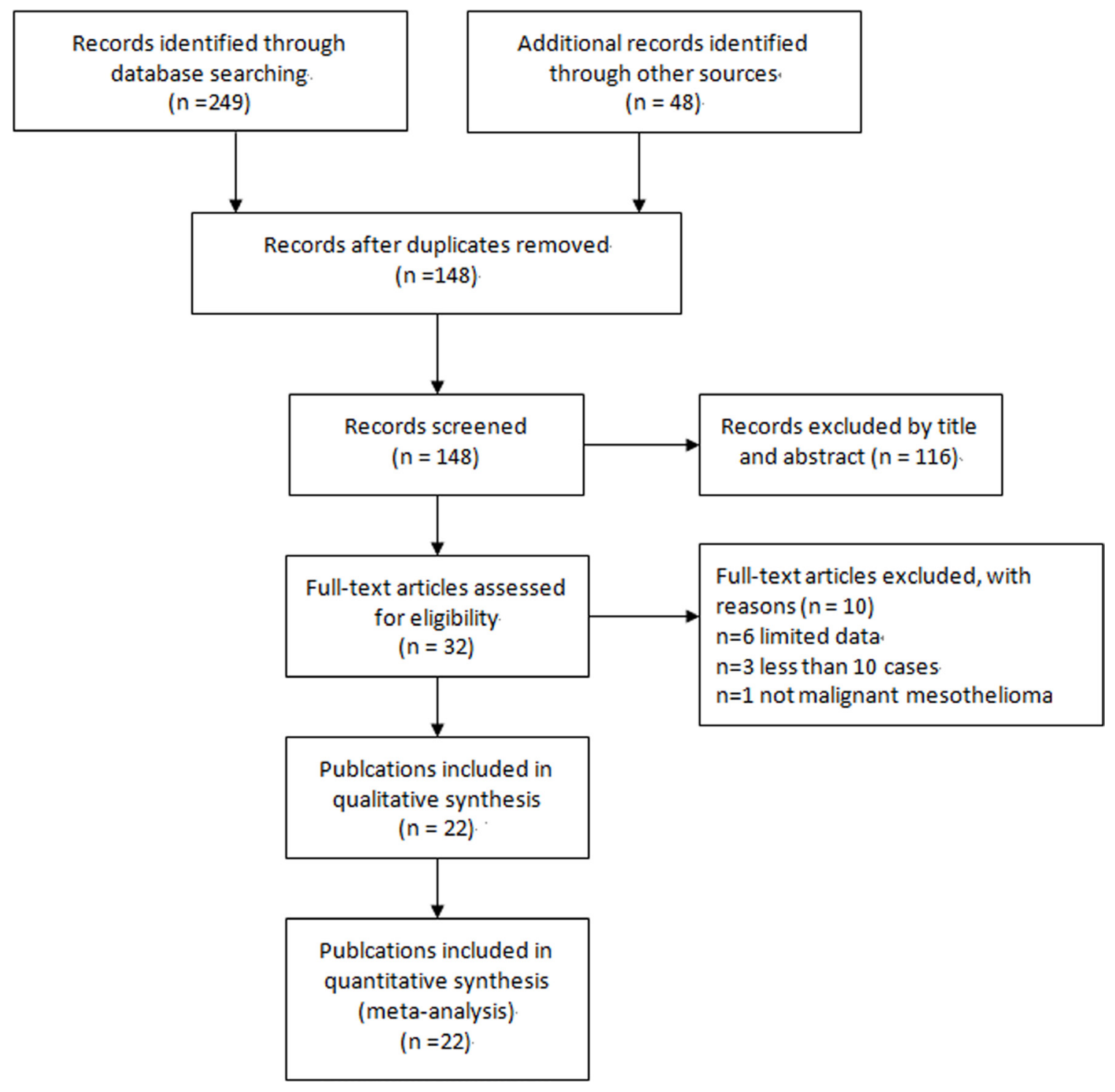

Figure 1: Flow diagram of literature search. 
Table 2: Diagnostic performance, design, and quality of included studies

\begin{tabular}{|c|c|c|c|c|c|c|c|c|c|}
\hline Author (Ref) & Cases & Controls & TP & FP & $\mathbf{F N}$ & $\mathbf{T N}$ & Design & Blinded? & QUADAS \\
\hline Bassarova AV [17] & 32 & 250 & 32 & 128 & 0 & 122 & NA & NA & 8 \\
\hline Saad RS [18] & 20 & 20 & 17 & 0 & 3 & 20 & $\mathrm{R}$ & Yes & 8 \\
\hline Bhalla R [19] & 10 & 10 & 10 & 0 & 0 & 10 & $\mathrm{R}$ & NA & 9 \\
\hline Hyun TS [20] & 11 & 21 & 9 & 0 & 2 & 21 & $\mathrm{R}$ & Yes & 10 \\
\hline Ordóñez NG [21] & 40 & 123 & 29 & 8 & 11 & 115 & NA & NA & 11 \\
\hline Chu AY [22] & 53 & 125 & 51 & 27 & 2 & 98 & $\mathrm{R}$ & NA & 12 \\
\hline Müller AM [23] & 36 & 76 & 22 & 27 & 14 & 49 & NA & NA & 10 \\
\hline Ordóñez NG [24] & 40 & 45 & 37 & 6 & 3 & 39 & NA & NA & 11 \\
\hline Comin CE [25] & 15 & 40 & 14 & 8 & 1 & 32 & $\mathrm{R}$ & NA & 9 \\
\hline Mimura T [26] & 66 & 66 & 56 & 3 & 10 & 63 & $\mathrm{R}$ & NA & 11 \\
\hline Padgett DM [27] & 44 & 101 & 38 & 4 & 6 & 97 & $\mathrm{R}$ & NA & 12 \\
\hline Amatya VJ [28] & 80 & 80 & 74 & 13 & 6 & 67 & $\mathrm{R}$ & NA & 12 \\
\hline Deniz H [29] & 37 & 36 & 19 & 0 & 18 & 36 & $\mathrm{R}$ & NA & 11 \\
\hline Takeshima Y [30] & 45 & 27 & 39 & 7 & 6 & 20 & $\mathrm{R}$ & NA & 10 \\
\hline $\mathrm{Hu} \mathrm{YC}[31]$ & 36 & 31 & 25 & 2 & 11 & 29 & $\mathrm{R}$ & NA & 10 \\
\hline Kao SC [32] & 80 & 21 & 80 & 0 & 0 & 21 & $\mathrm{R}$ & NA & 9 \\
\hline Comin CE [33] & 75 & 172 & 73 & 25 & 2 & 147 & $\mathrm{R}$ & NA & 10 \\
\hline Guo Z [8] & 43 & 35 & 38 & 24 & 5 & 11 & $\mathrm{R}$ & NA & 12 \\
\hline Kawai T [34] & 22 & 11 & 17 & 3 & 5 & 8 & $\mathrm{P}$ & NA & 11 \\
\hline Carbone M [5] & 10 & 45 & 8 & 10 & 2 & 35 & $\mathrm{R}$ & NA & 10 \\
\hline Amatya VJ [35] & 31 & 29 & 22 & 9 & 9 & 20 & $\mathrm{R}$ & Yes & 12 \\
\hline Kushitani K [36] & 36 & 38 & 35 & 23 & 1 & 15 & $\mathrm{R}$ & NA & 11 \\
\hline
\end{tabular}

NA: Not available; P: Prospective; R: Retrospective; FN: False negative; FP: False positive; TN: True negative;

TP: True positive; QUADAS: Quality assessment for diagnostic accuracy studies.
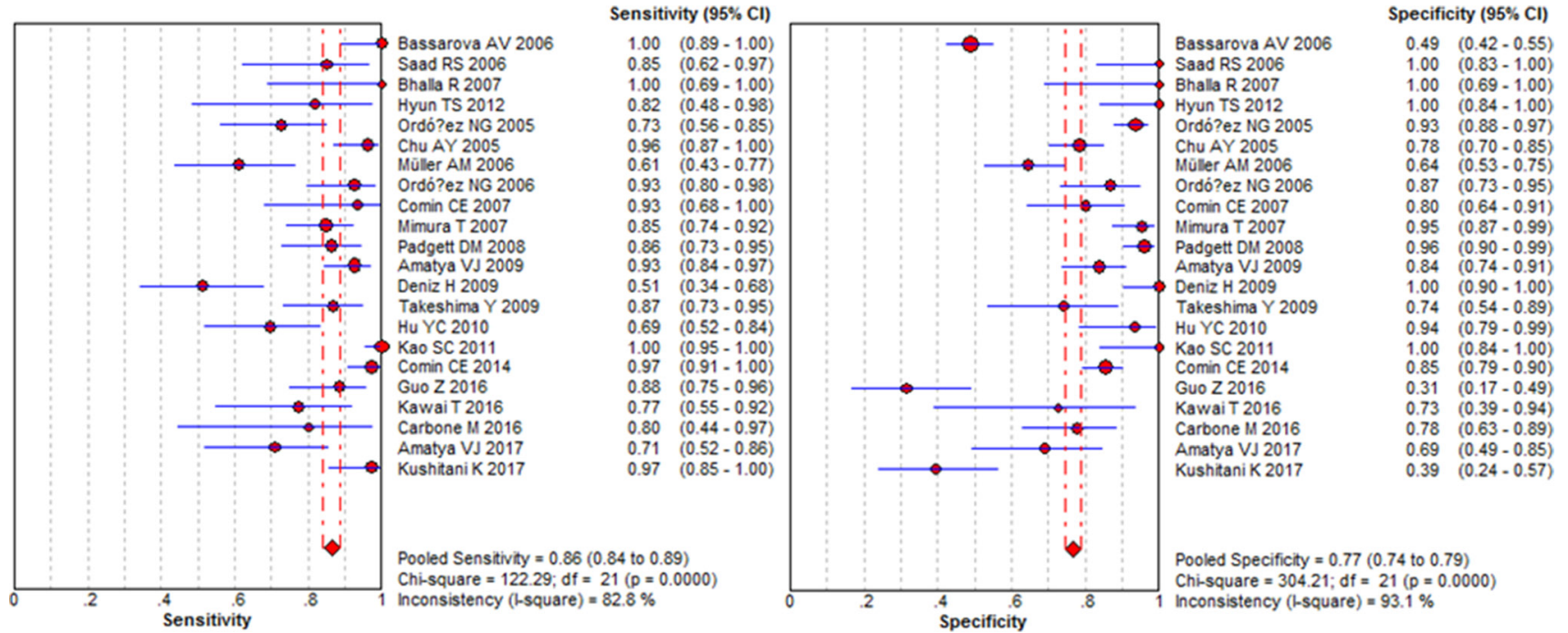

Figure 2: Forest plots of sensitivity and specificity for diagnosing malignant mesothelioma using D2-40 immunostaining. 
Table 3: Accuracy of D2-40 immunostaining for diagnosing malignant mesothelioma (MM)

\begin{tabular}{|c|c|c|c|c|c|c|c|c|c|}
\hline Carcinoma & $\begin{array}{l}\text { No. of } \\
\text { studies }\end{array}$ & Cases & Controls & AUC & SEN $[95 \% \mathrm{CI}]$ & SPE $[95 \% \mathrm{CI}]$ & PLR [95\% CI] & NLR [95\% CI] & DOR $[95 \%$ CI $]$ \\
\hline $\mathrm{MM}$ & 22 & 862 & 1402 & 0.93 & $0.86[0.84,0.89]$ & $0.77[0.74,0.79]$ & $5.15[3.30,8.03]$ & $0.18[0.12,0.27]$ & $40.37[19.97,81.61]$ \\
\hline Epithelioid MM & 16 & 540 & 1020 & 0.96 & $0.92[0.89,0.94]$ & $0.84[0.82,0.87]$ & $6.56[4.06,10.58]$ & $0.10[0.06,0.18]$ & $85.38[51.85,140.60]$ \\
\hline Biphasic MM & 9 & 85 & 559 & 0.94 & $0.80[0.70,0.88]$ & $0.90[0.87,0.92]$ & $8.27[4.22,16.21]$ & $0.24[0.08,0.70]$ & $43.14[15.53,119.82]$ \\
\hline Sarcomatoid MM & 10 & 131 & 659 & 0.83 & $0.65[0.56,0.73]$ & $0.84[0.81,0.87]$ & $3.29[1.75,6.16]$ & $0.52[0.29,0.92]$ & $6.93[2.05,23.47]$ \\
\hline Pleural MM & 13 & 536 & 707 & 0.93 & $0.85[0.82,0.88]$ & $0.81[0.78,0.84]$ & $5.12[2.94,8.90]$ & $0.19[0.11,0.33]$ & $42.98[15.21,121.39]$ \\
\hline
\end{tabular}

AUC, Area under the curve; CI: Confidential interval; SEN, Sensitivity; SPE, Specificity; PLR: Positive likelihood ratio; NLR: Negative likelihood ratio; DOR: Diagnostic odds ratio.

biological behavior among the subtypes of MM should be considered when using cytological diagnosis. Epithelioid MM cells readily shed into the pleural or peritoneal space, which can be identified from pleural or peritoneal effusions [42]. While, sarcomatoid MM cells generally do not shed into the pleural or peritoneal space, which leads to poor performance of cytological diagnosis [42].
Thus, cytology-only approach should be not suitable for diagnosing sarcomatoid MM and biphasic MM.

Because both benign and malignant mesothelial cells can react to D2-40 antibody [22, 43], it is needed to distinguish $\mathrm{MM}$ from reactive mesothelial hyperplasia in diagnostic practice. Several aspects (such as cellularity, papillae, zonation, growth pattern, vascularity and stromal
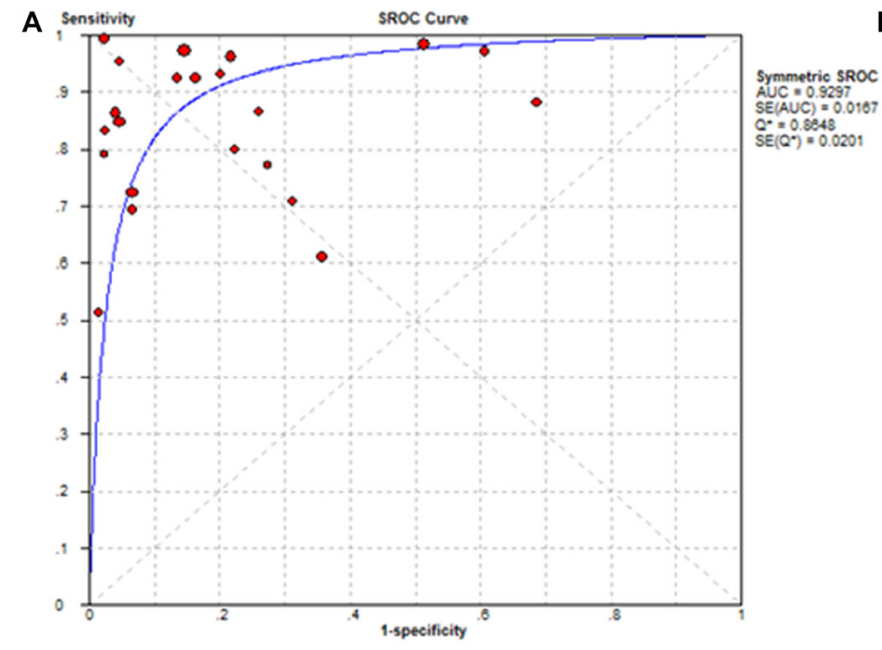

B
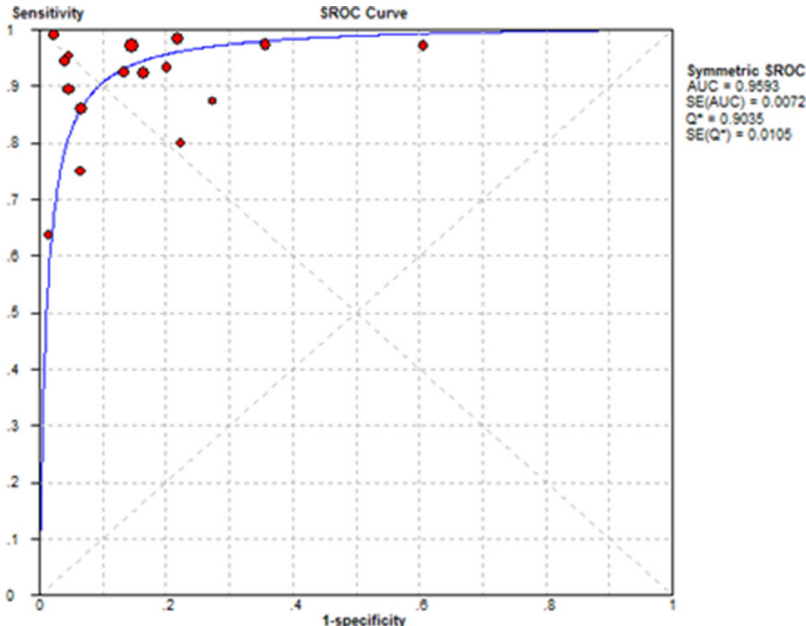
$E\left(Q^{\circ}\right)=0.0105$
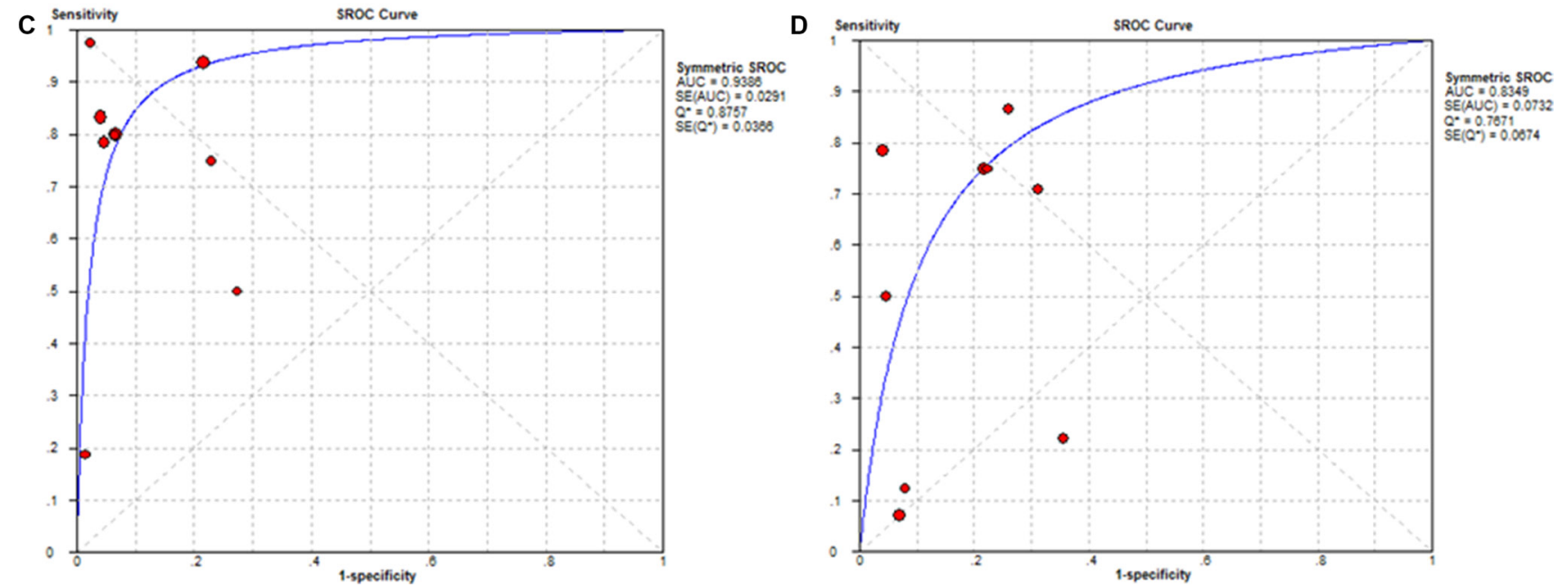

Figure 3: Summary receiver operating characteristic (SROC) curves for diagnosing malignant mesothelioma (MM) and its subtypes using D2-40 immunostaining. (A) MM (B) Epithelioid MM (C) Biphasic MM (D) Sarcomatoid MM. The SROC curves with confidence and prediction regions around mean operating sensitivity and specificity point analyses of D2-40. AUC, Area under the curve. 
Table 4: Meta-regression of potential heterogeneity among the included studies

\begin{tabular}{|c|c|c|c|c|c|}
\hline Covariates & No. of studies & Coefficient & SE & RDOR (95\% CI) & $P$ value \\
\hline \multicolumn{6}{|l|}{ Country } \\
\hline USA & 9 & -0.66 & 0.77 & $0.52(0.10-2.76)$ & 0.41 \\
\hline others & 13 & & & & \\
\hline \multicolumn{6}{|l|}{ Sample size } \\
\hline$<100$ & 13 & 0.87 & 0.70 & $2.39(0.52-10.96)$ & 0.24 \\
\hline$\geq 100$ & 9 & & & & \\
\hline \multicolumn{6}{|l|}{ Specimen } \\
\hline Effusion & 4 & -1.32 & 1.78 & $0.27(0.01-13.01)$ & 0.47 \\
\hline Tissue & 18 & & & & \\
\hline \multicolumn{6}{|l|}{ D2-40 dilution } \\
\hline$<1: 50$ & 5 & -1.10 & 0.96 & $0.33(0.04-2.72)$ & 0.27 \\
\hline others & 17 & & & & \\
\hline \multicolumn{6}{|l|}{ Cut-off } \\
\hline Membranous staining & 13 & -1.52 & 0.72 & $0.22(0.05-1.04)$ & 0.05 \\
\hline others & 9 & & & & \\
\hline \multicolumn{6}{|l|}{ Study Design } \\
\hline Prospective & 1 & -0.14 & 1.60 & $1.15(0.04-37.21)$ & 0.93 \\
\hline others & 21 & & & & \\
\hline \multicolumn{6}{|l|}{ Blinding } \\
\hline Yes & 3 & -0.97 & 1.30 & $0.38(0.02-6.53)$ & 0.47 \\
\hline NA & 19 & & & & \\
\hline \multicolumn{6}{|l|}{ QUADAS score } \\
\hline$<9$ & 2 & 1.08 & 2.10 & $2.95(0.03-289.83)$ & 0.62 \\
\hline$\geq 9$ & 20 & & & & \\
\hline
\end{tabular}

SE: Standard error; RDOR: Relative diagnostic odds ratio; CI: Confidential interval; NA: Not available; QUADAS: Quality assessment for diagnostic accuracy studies.

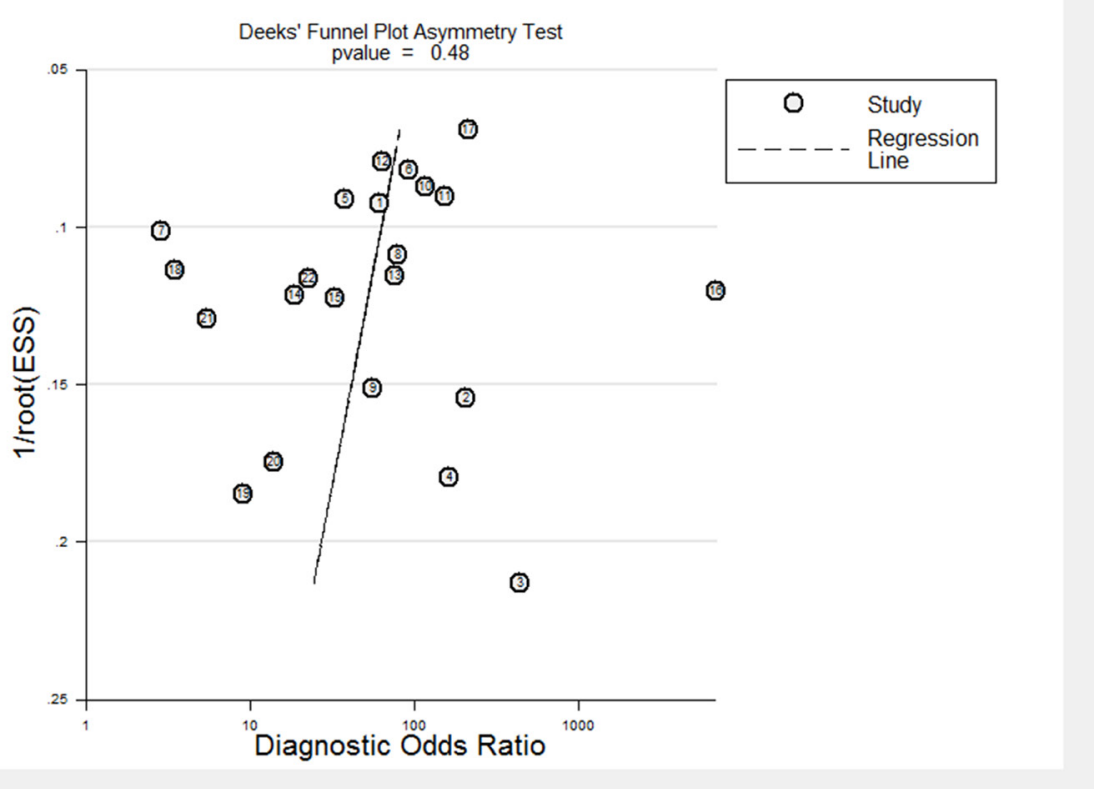

Figure 4: Deeks' funnel plot to assess the likelihood of publication bias. The $P$ value of 0.48 for the slope coefficient suggests symmetry in the data and a low likelihood of publication bias. 
invasion) should be considered [4, 39, 44]. A new tool, combining molecular data and computational analysis, has been applied for this kind of differential diagnosis [45].

In addition, the operation procedure of D2-40 immunostaining was not uniformed in the included studies. First, though all the included studies used D240 clone, its dilution factors ranged from 1:25 to 1:200. Second, cut-off value of positive staining is not consistent among the included studies. According to our experience in D2-40 immunostaining (D2-40 clone, 1:100, Dako, membrane staining), optimal condition, standard operation procedure, and reliable quality control are very important for obtaining satisfactory immunostaining results.

The findings of this meta-analysis should be interpreted with caution because of several limitations. We applied strict inclusion criteria, which may be good for reducing selection bias, but led to only a small set of studies could be included. In addition, we observed the substantial heterogeneity across the included studies, but we were unable to identify its source using metaregression analysis. Future work should aim to decrease the risk of bias.

\section{CONCLUSIONS}

In summary, our findings indicated that the accuracy of D2-40 immunostaining may be not enough to diagnose MM alone. The results of D2-40 immunostaining should be interpreted in combination with those of other markers. Novel promising markers are also needed to be explored to improve the diagnostic accuracy.

\section{Abbreviations}

MM, Malignant Mesothelioma; QUADAS, Quality Assessment for Diagnostic Accuracy Studies; 95\% CI, 95\% Confidence Interval; PLR, Positive Likelihood Ratio; NLR, Negative Likelihood Ratio; DOR, Diagnostic Odds Ratio; SROC, Summary Receiver Operating Characteristic; AUC, Area Under the Curve; SCC, Small Cell Carcinomas

\section{Authors' contributions}

Chao He and Bo Wang conceived, designed the study and wrote the paper. Chun Wan and Ting Yang performed data analysis and revised the manuscript. Yongchun Shen is guarantor of the paper, taking responsibility for the integrity of the work as a whole, from inception to published article.

\section{CONFLICTS OF INTEREST}

The authors declare no competing financial interests.

\section{REFERENCES}

1. Delgermaa V, Takahashi K, Park EK, Le GV, Hara T, Sorahan T. Global mesothelioma deaths reported to the World Health Organization between 1994 and 2008. Bull World Health Organ. 2011; 89:716-24, 24A-24C. https:// doi.org/10.2471/BLT.11.086678.

2. Robinson BW, Musk AW, Lake RA. Malignant mesothelioma. Lancet. 2005; 366:397-408. https://doi. org/10.1016/S0140-6736(05)67025-0.

3. Beebe-Dimmer JL, Fryzek JP, Yee CL, Dalvi TB, Garabrant DH, Schwartz AG, Gadgeel S. Mesothelioma in the United States: a Surveillance, Epidemiology, and End Results (SEER)-Medicare investigation of treatment patterns and overall survival. Clin Epidemiol. 2016; 8:743-50. https://doi.org/10.2147/CLEP.S105396.

4. Husain AN, Colby T, Ordonez N, Krausz T, Attanoos R, Beasley MB, Borczuk AC, Butnor K, Cagle PT, Chirieac LR, Churg A, Dacic S, Fraire A, et al. Guidelines for pathologic diagnosis of malignant mesothelioma: 2012 update of the consensus statement from the International Mesothelioma Interest Group. Arch Pathol Lab Med. 2013; 137:647-67. https://doi.org/10.5858/arpa.2012-0214-OA.

5. Carbone M, Shimizu D, Napolitano A, Tanji M, Pass HI, Yang H, Pastorino S. Positive nuclear BAP1 immunostaining helps differentiate non-small cell lung carcinomas from malignant mesothelioma. Oncotarget. 2016; 7:59314-21. https://doi.org/10.18632/ oncotarget.10653.

6. Goldberg M, Imbernon E, Rolland P, Gilg Soit Ilg A, Saves M, de Quillacq A, Frenay C, Chamming's S, Arveux P, Boutin C, Launoy G, Pairon JC, Astoul P, et al. The French National Mesothelioma Surveillance Program. Occup Environ Med. 2006; 63:390-5. https://doi.org/10.1136/ oem.2005.023200.

7. Carbone M, Kanodia S, Chao A, Miller A, Wali A, Weissman D, Adjei A, Baumann F, Boffetta P, Buck B, de Perrot M, Dogan AU, Gavett S, et al. Consensus Report of the 2015 Weinman International Conference on Mesothelioma. J Thorac Oncol. 2016; 11:1246-62. https:// doi.org/10.1016/j.jtho.2016.04.028.

8. Guo Z, Carbone M, Zhang X, Su D, Sun W, Lou J, Gao Z, Shao D, Chen J, Zhang G, Hu J, Chen K, Wang F, et al. Improving the Accuracy of Mesothelioma Diagnosis in China. J Thorac Oncol. 2016; 12:714-723. https://doi. org/10.1016/j.jtho.2016.12.006.

9. Marks A, Sutherland DR, Bailey D, Iglesias J, Law J, Lei M, Yeger H, Banerjee D, Baumal R. Characterization and distribution of an oncofetal antigen (M2A antigen) expressed on testicular germ cell tumours. Br J Cancer. 1999; 80:569-78. https://doi.org/10.1038/sj.bjc.6690393.

10. Kahn HJ, Bailey D, Marks A. Monoclonal antibody D2-40, a new marker of lymphatic endothelium, reacts with Kaposi's sarcoma and a subset of angiosarcomas. 
Mod Pathol. 2002; 15:434-40. https://doi.org/10.1038/ modpathol.3880543.

11. Ensani F, Nematizadeh F, Irvanlou G. Accuracy of immunohistochemistry in evaluation of malignant pleural and peritoneal effusions. Pol J Pathol. 2011; 62:95-100.

12. Kim JH, Kim GE, Choi YD, Lee JS, Lee JH, Nam JH, Choi C. Immunocytochemical panel for distinguishing between adenocarcinomas and reactive mesothelial cells in effusion cell blocks. Diagn Cytopathol. 2009; 37:258-61. https://doi.org/10.1002/dc.20986.

13. Lyons-Boudreaux V, Mody DR, Zhai J, Coffey D. Cytologic malignancy versus benignancy: how useful are the "newer" markers in body fluid cytology? Arch Pathol Lab Med. 2008; 132:23-8. https://doi.org/10.1043/15432165(2008)132[23:CMVBHU]2.0.CO;2.

14. Dinu M, Ciurea RN, Stefan M, Georgescu AC. The role of immunohistochemistry in the diagnosis of neoplastic pleural effusions. Rom J Morphol Embryol. 2012; 53:817-20.

15. Whiting PF, Weswood ME, Rutjes AW, Reitsma JB, Bossuyt PN, Kleijnen J. Evaluation of QUADAS, a tool for the quality assessment of diagnostic accuracy studies. BMC Med Res Methodol. 2006; 6:9. https://doi.org/10.1186/14712288-6-9.

16. Deeks JJ, Macaskill P, Irwig L. The performance of tests of publication bias and other sample size effects in systematic reviews of diagnostic test accuracy was assessed. J Clin Epidemiol. 2005; 58:882-93. https://doi.org/10.1016/j. jclinepi.2005.01.016.

17. Bassarova AV, Nesland JM, Davidson B. D2-40 is not a specific marker for cells of mesothelial origin in serous effusions. Am J Surg Pathol. 2006; 30:878-82. https://doi. org/10.1097/01.pas.0000208280.29291.34.

18. Saad RS, Lindner JL, Lin X, Liu YL, Silverman JF. The diagnostic utility of D2-40 for malignant mesothelioma versus pulmonary carcinoma with pleural involvement. Diagn Cytopathol. 2006; 34:801-6. https://doi.org/10.1002/ dc.20556.

19. Bhalla R, Siddiqui MT, Mandich D, Cartun RW, FielGan MD, Nassar A, Mandavilli SR. Diagnostic utility of D240 and podoplanin in effusion cell blocks. Diagn Cytopathol. 2007; 35:342-7. https://doi.org/10.1002/dc.20633.

20. Hyun TS, Barnes M, Tabatabai ZL. The diagnostic utility of D2-40, calretinin, CK5/6, desmin and MOC-31 in the differentiation of mesothelioma from adenocarcinoma in pleural effusion cytology. Acta Cytol. 2012; 56:527-32. https://doi.org/10.1159/000339586.

21. Ordonez NG. D2-40 and podoplanin are highly specific and sensitive immunohistochemical markers of epithelioid malignant mesothelioma. Hum Pathol. 2005; 36:372-80. https://doi.org/10.1016/j.humpath.2005.01.019.

22. Chu AY, Litzky LA, Pasha TL, Acs G, Zhang PJ. Utility of D2-40, a novel mesothelial marker, in the diagnosis of malignant mesothelioma. Mod Pathol. 2005; 18:105-10. https://doi.org/10.1038/modpathol.3800259.

23. Muller AM, Franke FE, Muller KM. D2-40: a reliable marker in the diagnosis of pleural mesothelioma. Pathobiology. 2006; 73:50-4. https://doi.org/10.1159/000093091.

24. Ordonez NG. The diagnostic utility of immunohistochemistry and electron microscopy in distinguishing between peritoneal mesotheliomas and serous carcinomas: a comparative study. Mod Pathol. 2006; 19:34-48. https:// doi.org/10.1038/modpathol.3800471.

25. Comin CE, Saieva C, Messerini L. h-caldesmon, calretinin, estrogen receptor, and Ber-EP4: a useful combination of immunohistochemical markers for differentiating epithelioid peritoneal mesothelioma from serous papillary carcinoma of the ovary. Am J Surg Pathol. 2007; 31:1139-48. https://doi.org/10.1097/PAS.0b013e318033e7a8.

26. Mimura T, Ito A, Sakuma T, Ohbayashi C, Yoshimura M, Tsubota N, Okita Y, Okada M. Novel marker D2-40, combined with calretinin, CEA, and TTF-1: an optimal set of immunodiagnostic markers for pleural mesothelioma. Cancer. 2007; 109:933-8. https://doi.org/10.1002/ cncr. 22477.

27. Padgett DM, Cathro HP, Wick MR, Mills SE. Podoplanin is a better immunohistochemical marker for sarcomatoid mesothelioma than calretinin. Am J Surg Pathol. 2008; 32:123-7. https://doi.org/10.1097/PAS.0b013e31814faacf.

28. Amatya VJ, Takeshima Y, Kohno H, Kushitani K, Yamada T, Morimoto C, Inai K. Caveolin-1 is a novel immunohistochemical marker to differentiate epithelioid mesothelioma from lung adenocarcinoma. Histopathology. 2009; 55:10-9. $\quad$ https://doi.org/10.1111/j.13652559.2009.03322.x.

29. Deniz H, Kibar Y, Guldur ME, Bakir K. Is D2-40 a useful marker for distinguishing malignant mesothelioma from pulmonary adenocarcinoma and benign mesothelial proliferations? Pathol Res Pract. 2009; 205:749-52. https:// doi.org/10.1016/j.prp.2009.06.001.

30. Takeshima Y, Amatya VJ, Kushitani K, Kaneko M, Inai K. Value of immunohistochemistry in the differential diagnosis of pleural sarcomatoid mesothelioma from lung sarcomatoid carcinoma. Histopathology. 2009; 54:667-76. https://doi.org/10.1111/j.1365-2559.2009.03298.x.

31. Hu Y, Yang Q, McMahon LA, Wang HL, Xu H. Value of D2-40 in the differential diagnosis of pleural neoplasms with emphasis on its positivity in solitary fibrous tumor. Appl Immunohistochem Mol Morphol. 2010; 18:411-3. https://doi.org/10.1097/PAI.0b013e3181da8387.

32. Kao SC, Griggs K, Lee K, Armstrong N, Clarke S, Vardy J, van Zandwijk N, Burn J, McCaughan BC, Henderson DW, Klebe S. Validation of a minimal panel of antibodies for the diagnosis of malignant pleural mesothelioma. Pathology. 2011; 43:313-7. https://doi.org/10.1097/ PAT.0b013e32834642da.

33. Comin CE, Novelli L, Cavazza A, Rotellini M, Cianchi F, Messerini L. Expression of thrombomodulin, calretinin, cytokeratin 5/6, D2-40 and WT-1 in a series of primary carcinomas of the lung: an immunohistochemical study in comparison with epithelioid pleural mesothelioma. Tumori. 
2014; 100:559-67. https://doi.org/10.1700/1660.18182.

34. Kawai T, Tominaga S, Hiroi S, Ogata S, Nakanishi K, Kawahara K, Sonobe H, Hiroshima K. Peritoneal malignant mesothelioma (PMM), and primary peritoneal serous carcinoma (PPSC) and reactive mesothelial hyperplasia (RMH) of the peritoneum. Immunohistochemical and fluorescence in situ hybridisation (FISH) analyses. J Clin Pathol. 2016; 69:706-12. https://doi.org/10.1136/ jclinpath-2015-203211.

35. Amatya VJ, Kushitani K, Mawas AS, Miyata Y, Okada M, Kishimoto $\mathrm{T}$, Inai $\mathrm{K}$, Takeshima Y. MUC4, a novel immunohistochemical marker identified by gene expression profiling, differentiates pleural sarcomatoid mesothelioma from lung sarcomatoid carcinoma. Mod Pathol. 2017; 30:672-681. https://doi.org/10.1038/modpathol.2016.181.

36. Kushitani K, Amatya VJ, Okada Y, Katayama Y, Mawas AS, Miyata Y, Okada M, Inai K, Kishimoto T, Takeshima Y. Utility and pitfalls of immunohistochemistry in the differential diagnosis between epithelioid mesothelioma and poorly differentiated lung squamous cell carcinoma. Histopathology. 2017; 70:375-84. https://doi.org/10.1111/ his. 13073.

37. Creaney J, Robinson BW. Malignant mesothelioma biomarkers - from discovery to use in clinical practise for diagnosis, monitoring, screening and treatment. Chest. 2016; 152:143-149. https://doi.org/10.1016/j.chest.2016.12.004.

38. Lee BH, Hecht JL, Pinkus JL, Pinkus GS. WT1, estrogen receptor, and progesterone receptor as markers for breast or ovarian primary sites in metastatic adenocarcinoma to body fluids. Am J Clin Pathol. 2002; 117:745-50. https:// doi.org/10.1309/QLV6-HH0H-UCTF-WEF6.

39. Travis WD, Brambilla E, Burke AP, Marx A, Nicholson AG. Introduction to The 2015 World Health Organization Classification of Tumors of the Lung, Pleura, Thymus, and Heart. J Thorac Oncol. 2015; 10:1240-2. https://doi. org/10.1097/JTO.0000000000000663.

40. Chirieac LR, Pinkus GS, Pinkus JL, Godleski J, Sugarbaker DJ, Corson JM. The immunohistochemical characterization of sarcomatoid malignant mesothelioma of the pleura. Am J Cancer Res. 2011; 1:14-24.

41. Ren R, Yin P, Zhang Y, Zhou J, Zhou Y, Xu R, Lin H, Huang C. Diagnostic value of fibulin-3 for malignant pleural mesothelioma: A systematic review and meta-analysis. Oncotarget. 2016; 7:84851-9. https://doi.org/10.18632/ oncotarget.12707.

42. Muruganandan S, Alfonso H, Franklin P, Shilkin K, Segal A, Olsen N, Reid A, de Klerk N, Musk AB, Brims F. Comparison of outcomes following a cytological or histological diagnosis of malignant mesothelioma. Br J Cancer. 2017; 116:703-708. https://doi.org/10.1038/bjc.2017.20.

43. Ordonez NG. Immunohistochemical diagnosis of epithelioid mesothelioma: an update. Arch Pathol Lab Med. 2005; 129:1407-14. https://doi.org/10.1043/15432165(2005)129[1407:IDOEMA]2.0.CO;2.

44. Galateau-Salle F, Churg A, Roggli V, Travis WD; World Health Organization Committee for Tumors of the Pleura. The 2015 World Health Organization Classification of Tumors of the Pleura: Advances since the 2004 Classification. J Thorac Oncol. 2016; 11:142-54. https:// doi.org/10.1016/j.jtho.2015.11.005.

45. Bruno R, Ali G, Giannini R, Proietti A, Lucchi M, Chella A, Melfi F, Mussi A, Fontanini G. Malignant pleural mesothelioma and mesothelial hyperplasia: A new molecular tool for the differential diagnosis. Oncotarget. 2017; 8:2758-70. https://doi.org/10.18632/ oncotarget.13174. 